\title{
REFORMASI ADMINISTRASI MENUJU PUBLIC SERVICEDALAM SEKTOR PENDIDIKAN, KESEHATAN, DAN EKONOMI MASYARAKAT PADA PEMERINTAH DAERAH
}

\author{
ADRIANI ADNANI \\ STISIPOL Imam Bonjol Padang
}

\begin{abstract}
The role and character of state institutions and the public sector are more directed to be oriented towards the community. This condition initially occurred in various developed countries, which then spread to developing countries. Of course, many factors caused this to happen, such as the economic and financial crisis of the state. Public administration reform towards public service is important enough to get attention and treatment as soon as possible. The dynamics of society as a social force cannot be ignored in the system of control and public accountability, both in service delivery and in the implementation of development. The purpose of this study is to find out the New Public Service paradigm as a new concept in administrative reform in the education, health and economic sectors of the local government. The results of the study indicate that public services in the education, health, and economic sectors of today's society are facing a trend towards the development of regional governance as a result of globalization and regional autonomy. In the management of local government, a change and renewal is needed so that the government can always accommodate the needs of change in society and enable public administration to reorganize people's lives. One of the trends in the need for public bureaucracy to reform is that local government bureaucracies must be more open in relation to the public interest. In other words, the local government bureaucracy can become more flexible so that it can more easily adapt to changing circumstances. With the administrative reform towards public service, it is hoped that it can encourage the realization of good governance, improve performance and improve unhealthy administrative practices.
\end{abstract}

Keywords:Reform, Administration, Public Services.

Abstrak: Peran dan karakter lembaga negara dan sektor publik lebih diarahkan untuk berorientasi pada masyarakat. Kondisi ini awalnya terjadi di berbagai negara maju, yang kemudian menyebar ke negara berkembang. Tentu banyak faktor yang menyebabkan hal itu terjadi, seperti krisis ekonomi dan keuangan negara. Reformasi administrasi publik menuju pelayanan publik cukup penting untuk mendapatkan perhatian dan penanganan sesegera mungkin. Dinamika masyarakat sebagai kekuatan sosial tidak dapat diabaikan dalam sistem kontrol dan akuntabilitas publik, baik dalam pemberian pelayanan maupun dalam pelaksanaan pembangunan. Tujuan dari penelitian ini adalah untuk mengetahui paradigma New Public Service sebagai konsep baru dalam reformasi administrasi di bidang pendidikan, kesehatan dan ekonomi pemerintah daerah. Hasil penelitian menunjukkan bahwa pelayanan publik di sektor pendidikan, kesehatan, dan ekonomi masyarakat saat ini menghadapi kecenderungan perkembangan pemerintahan daerah sebagai akibat dari globalisasi dan otonomi daerah. Dalam penyelenggaraan pemerintahan daerah diperlukan suatu perubahan dan pembaharuan agar pemerintah selalu dapat mengakomodir kebutuhan perubahan masyarakat dan memungkinkan administrasi publik menata kembali kehidupan masyarakat. Salah satu kecenderungan perlunya reformasi birokrasi publik adalah birokrasi pemerintah daerah harus lebih terbuka dalam kaitannya dengan kepentingan publik. Dengan kata lain, birokrasi pemerintah daerah dapat menjadi lebih fleksibel sehingga dapat lebih mudah beradaptasi dengan perubahan keadaan. Dengan reformasi administrasi menuju pelayanan publik diharapkan dapat mendorong terwujudnya good governance, meningkatkan kinerja dan memperbaiki praktik administrasi yang tidak sehat.

Kata Kunci: Reformasi, Administrasi, Pelayanan Publik. 


\section{A. Pendahuluan}

Selama lebih dari beberapa dekade, gelombang reformasi yang membawa perubahan terhadap manajemen sektor publik telah melanda berbagai negara, baik negara berkembang, maupun negara yang sedang berada dalam masa transisi. Peran dan karakter kelembagaan negara dan sektor publik lebih diarahkan untuk berorientasi terhadap masyarakat. Kondisi ini awalnya terjadi di berbagai negara maju, yang kemudian merambat ke negara-negara berkembang. Tentunya banyak faktor yang menyebabkan hal ini terjadi, seperti krisis ekonomi dan keuangan negara. Krisis ekonomi dan keuangan membuat peran aktif negara diragukan dan menjadi pertanyaan yang serius. Pada negara maju seperti Inggris, Kanada, dan Australia, krisis kesejahteraan yang terjadi menyebabkan terbukanya peluang terhadap alternatif baru untuk mengatur dan mengelola pelayanan publik. Selain itu, pendefinisian kembali terhadap peran negara pasca krisis yang terjadi akan memberikan keunggulan yang lebih terhadap kompetisi pasar, dan persaingan dengan terbukanya jalan bagi sektor swasta dan sosial. Dalam kondisi yang sama, krisis ekonomi dan fiskal yang melanda sebagian besar negara berkembang pada 1980-an dan 1990-an menyebabkan pemikiran ulang bagi negara untuk dapat memimpin pembangunan dengan meningkatkan ukuran, fungsi, dan kekuasaan birokrasinya.

Denhardt \& Denhardt (2011) memetakan perubahan paradigma administrasi negara ke dalam 3 periode, yaitu "The Old Public Administration", "New Public Management", dan "New Public Service". Paradigma "The Old Public Administration" menempatkan warga masyarakat sebagai clients yang posisinya bersifat powerless. Kondisi menyebabkan warga masyarakat menjadi pihak yang harus menurut terhadap pelayanan yang diberikan birokrat. Hal inilah yang kemudian menjadi awal bagi reformasi di bidang administrasi negara. Mulai tahun 1990-an Ilmu Administrasi Publik mengenalkan paradigma baru yang sering disebut New Public Management (NPM). Pada dasarnya, paradigma ini memiliki penekanan pada perilaku pemerintah agar menjadi lebih efektif dan efisien. Hal ini dapat dilakukan dengan mengurangi peran pemerintah, membuka peran swasta, sehingga pemerintah lebih berfokus pada kepentingan publik dalam skala yang lebih luas. Paradigma NPM menempatkan warga masyarakat sebagai pelanggan, yang dalam konteks ini kualitas pelayanan publik sangat ditentukan oleh kemampuan ekonomi konsumen. Pada era ini, konsep mewirausahakan birokrasi mewarnai pelayanan publik di berbagai negara (Gaebler \& Osborne, 2003).

Kemunculannya ditengah kondisi perekonomian dan keuangan negara yang sedang mengalami masa krisis tentu saja paradigma ini tidak terlepas dari kritik. Kritik yang terjadi terhadap paradigma NPM utamanya bersumber dari kekhawatiran akan tergerusnya idealisme pelayanan publik dengan adanya kapitalisme dalam sektor publik, termasuk pada sektor pendidikan, kesehatan, dan ekonomi masyarakat. Beberapa pihak bahkan berpendapat bahwa NPM tidak tepat diterapkan untuk negara-negara berkembang. Hal ini disebabkan kesulitan yang dihadapi dalam proses pengimplementasiannya, sebagai akibat dari kecenderungan birokrasi yang sulit dihilangkan.Akhirnya, lahirlah paradigma terkini, yaitu New Public Service (NPS) menempatkan warga masyarakt sebagai citizen yang memiliki hak-hak untuk mendapatkan pelayanan publik yang memadai dari negara. Dalam konteks ini, birokrasi publik dituntut untuk mengubah paradigma dari government ke governance. Secara tegas, NPS menyodorkan doktrin baru dalam studi administrasi publik, yaitu: (1) serve citizens, not customers, (2) seek the public interest, (3) value citizenship over entrepreneurship, (4) think strategically, act democratically, (5) recognize that accountability is not simple, (6) serve rather than steer, (7) value people, not just productivity.

\section{B. Metodolohgi Penelitian}

Reformasi administrasi publik menuju public service cukup penting untuk mendapat perhatian dan penanganan secepatnya. Dinamika masyarakat sebagai kekuatan sosial tidak dapat diabaikan dalam sistem kontrol dan akuntabilitas publik, baik dalam penyelenggaraan pelayanan maupun dalam pelaksanaan pembangunan. Kesadaran masyarakat mengenai pentingnya keterbukaan dan kebertanggungjawaban dari birokrasi pemerintahan. Kondisi dan 
perkembangan masyarakat saat ini semakin dinamis sehingga sadar mengenai apa yang menjadi hak dan kewajibannya sebagai warga negara dalam hidup bermasyarakat dan bernegara. Selain itu, masyarakat semakin berani untuk mengajukan tuntutan, keinginan, dan aspirasinya kepada pemerintah. Dalam hubungan itu birokrasi dituntut melakukan revitalisasi dalam menjalankan tugas dan kewenangan yang diberikan kepadanya untuk mewujudkan harapan publik. Karena itu dengan semangat demokratisasi juga membawa cakrawala baru bagi birokrasi pemerintah untuk lebih responsif dalam rangka mempercepat kemajuan masyarakat kearah yang lebih baik melalui pengembangan kemampuan birokrasi publik. Oleh karena itu, perlu dilakukan pengkajian lebih lanjut atas permasalahan: "Bagaimanakah paradigma New Public Service sebagai konsep baru dalam reformasi administrasi pada sektor pendidikan, kesehatan dan ekonomi masyarakat di pemerintah daerah?"

\section{Hasil dan Pembahasan}

Pengalaman pelaksanaan reformasi administrasi di negara berkembang telah melahirkan banyak premis. Dalam hubungan ini, Zauhar (2006: 47) melihat bahwa reformasi administrasi merupakan suatu pola yang penunjukan peningkatan efektivitas pemanfaatan sumber daya yang tersedia untuk mencapai tujuan yang telah ditetapkan. Dengan demikian dalam reformasi administrasi, perhatian lebih dicurahkan pada upaya dan bukan semata-mata hasil. Secara internal tujuan reformasi adalah untuk menyempurnakan atau meningkatkan kinerja. Adapun secara eksternal yang berkaitan dengan masyarakat adalah menyesuaikan sistem administrasi terhadap meningkatnya kebutuhan masyarakat, Riggs (2006: 94), melihat reformasi atau pembaharuan dari dua sisi, yaitu perubahan struktur dan kinerja.

Secara struktural, adanya penggunaan diferensiasi struktural sebagai salah satu ukuran. Pandangan ini didasarkan pada kecenderungan peran-peran yang makin terspesialisasikan dan pembagian kerja yang makin tajam dan intens dalam masyarakat modern. Adapun mengenai kinerja, ditekankan sebagai ukuran bukan hanya kinerja yang lain atau organisasi secara keseluruhan. Wallis (2009) mengatakan bahwa pembaharuan administrasi meliputi tiga aspek, yaitu bahwa suatu perubahan harus merupakan perbaikan dari keadaan sebelumnya, perbaikan diperoleh dengan upaya yang disengaja dan bukan terjadi secara kebetulan, perbaikan yang terjadi bersifat jangka panjang dan tidak sementara.

Perspektif yang berbeda, Katz (2007) melakukan analisis yang lebih mutakhir mengenai keadaan administrasi di negara berkembang dan mengungkapkan bahwa upaya memperbaiki kinerja birokrasi pemerintahan harus meliputi ketanggapan sumber daya dan efektivitas dalam pemberian pelayanan. Reformasi administrasi merupakan suatu usaha sadar dan terencana untuk perbaikan insitusi dan perbaikan perilaku orang yang terlibat di dalamnya, Zauhar (2006) berpandangan bahwa tujuan dilakukannya reformasi administrasi adalah menyempurnakan tatanan, menyempurnakan metode, dan menyempurnakan kinerja.

1. Penyempurnaan Tatanan. Baik dalam masyarakat modern, keteraturan merupakan kebajikan yang melekat dalam pemerintahan. Kebanyakan reformasi administrasi yang dilakukan di negara-negara berkembang adalah atas inisiatif para birokrat yang inspirasi pembaharuannya didasarkan pada administrasi kolonial. Apabila yang ingin dituju adalah penyempurnaan tatanan maka tentunya reformasi harus diorientasikan pada penataan prosedur dan kontrol.

2. Penyempurnaan Metode. Para administrator merupakan pekerja teknis yang mengetahui banyak tentang metode kerja. Sebagai akibatnya maka mereka harus fanatik terhadap metode. Oleh karena itu, apabila masyarakat semakin mendukung terhadap adanya administrator teknis maka administrator harus semakin fanatik terhadap metode. Sebaliknya, apabila masyarakat semakin berorientasi pada status maka semakin berkurang tuntutan terhadap yang fanatik pada metode. Salah satu manfaat yang dapat diperoleh dari kejadian seperti itu adalah mampu merangsang diterimanya metode dan teknik baru tersebut secara gradual, yang kemudian disusul dengan usaha untuk menyebarluaskan metode yang ada ke seluruh tatanan sistem administrasi. Apabila tujuan utama reformasi administrasi diartikan dengan baik dan secara efektif 
diterjemahkan ke dalam berbagai program aksi yang memperbaiki implementasi program dapat meningkatkan realisasi pencapaian tujuan.

3. Perbaikan Kinerja. Perbaikan kinerja lebih bernuansa tujuan dalam substansi program kerjanya daripada penyempurnaan keteraturan maupun penyempurnaan metode teknis administratif. Titik perhatiannya adalah pergeseran dari bentuk ke substansi, pergeseran dari efisiensi ke efektivitas kerja, pergeseran dari kecakapan birokrasi ke kesejahteraan masyarakat. Model administrasi seperti inilah yang sulit dijumpai di kebanyakan negara berkembang. Penekanan baru terhadap kinerja program hanya akan ada apabila pemerintah negara sedang berkembang menginginkan pembangunan sosial ekonomi yang sungguh-sungguh. Begitu keinginan seperti ini muncul maka melahirkan pendekatan baru yang mempunyai sifat yang khas dalam reformasi administrasi. Caiden (2010) mengatakan bahwa reformasi yang benar yang seharusnya dilakukan di negaranegara sedang berkembang adalah yang bersifat pragramatik. Salah satu unsur penting untuk memperbaiki administrasi dalam hubungannya dengan masyarakat adalah mengembangkan akuntabilitas, karena masalah akuntabilitas merupakan hakikat dari upaya pembaharuan administrasi (Riggs, 2006).

Pelayanan publik yang berkualitas dan pantas, telah menjadi tuntutan masyarakat seiring dengan berkembangnya kesadaran masyarakat yang lebih demokratis. Peran pemerintah sebagai governor-governed, dan regulator-regulated harus memberikan peluang kepada warga masyarakat untuk ikut berpartisipasi dalam kehidupan bermasyarakat dan bernegara. Regulasi pelayanan publik yang masih tersebar dalam banyak peraturan yang sifatnya sektoral, menjadikan pelayanan publik di berbagai daerah di Indonesia berada pada kondisi yang belum manageable.Pergeseran kondisi masyarakat ini seiring dengan pergeseran paradigma di lingkungan ilmu administrasi publik yang mengarah ke paradigma baru yang disebut The New Public Service Paradigm. Faktanya, hukum administrasi yang mengatur pelayanan publik dan standar pelayanan publik di berbagai daerah sangat bervariasi sehubungan dengan kondisi sosial, budaya, dan kebutuhan masyarakat di masing-masing wilayah. Hukum administrasi bidang pelayanan publik diselenggarakan berdasar komitmen bersama penyelenggara dan masyarakat dalam model partisipasi. Hukum administrasi negara bidang pelayanan publik dikonstruksi oleh masyarakat dan penyelenggara pelayanan publik dalam forum partisipasi dan pelibatan berbagai pihak.

Kondisi tersebut kemduian memunculkan urgensi terhadap pengaturan pelayanan publik dengan suatu regulasi yang tanggap pada tuntutan masyarakat daerah. Konstruksi hukum dan standar pelayanan yang disusun secara konstruktif dan lebih responsif, dengan mengundang partisipasi masyarakat, dipandang perlu untuk diproses lebih lanjut, sehingga tidak lagi berwujud penetapan normatif yang sentral, melainkan sudah berupa kontrak pelayanan antara pemerintah daerah dan masyarakat setempat. Pelayanan untuk kepentingan publik seperti itu amat mendesak untuk segera diwacanakan, dan disimpulkan, sehingga dapat dipakai sebagai sumber hukum yang materiil dalam mengkonstruksi hukum untuk pelayanan publik.Model kontrak pelayanan secara teoretik dan konseptual mencerminkan adanya hukum yang tidak hanya responsif akan tetapi juga progresif dan demokratik. Tuntutan masyarakat untuk mendapatkan pelayanan publik yang berkualitas, berprosedur jelas, dilaksanakan dengan segera, dan dengan biaya yang pantas, telah terus mengedepan dari waktu ke waktu. Tuntutan ini berkembang seiring dengan berkembangnya kesadaran bahwa warga negara dalam kehidupan bernegara bangsa yang demokratik memiliki hak untuk dilayani. Tugas dan sekaligus wewenang pemerintah untuk bertindak sebagai regulator dan sekaligus implementator kebijakan. Pemerintah telah mendudukkan diri di satu pihak sebagai pemberi perintah, yang akan memposisikan dirinya berhadap-hadapan dengan yang diperintah, dalam hubungan governor-governed atau regulator-regulated.

Regulasi pelayanan publik yang sifatnya tersebar dalam banyak peraturan yang sifatnya sektoral, dengan standar yang berbeda-beda, menjadikan pelayanan publik di Indonesia berada pada kondisi yang belum manageable. Perubahan yang terjadi di bidang sosial-kultural dan 
politik berdampak pada terjadinya pergeseran yang akan menuju ke paradigma hukum responsif, yang bisa diduga akan dapat memenuhi tututan dan kebutuhan masyarakat yang sangat mendesak untuk memperoleh pelayanan yang berkeadilan sosial. Pergeseran paradigma administrasi publik, menuju ke New Public Service Paradigm yang lebih partisipatif, berkeadilan, transparan, berkepastian dan terjangkau merupakan agenda reformasi yang sangat tepat bagi administrasi publik.

Philippe Nonet dan Philip Selznick mencoba menjawab kebutuhan akan suatu teori hukum yang mampu memperkuat nilai hukum dan menunjukkan alternatif-alternatif bagi pemaksaan dan penekanan, memenuhi tututan-tuntutan serta ketutuhankebutuhan sosial yang sangat mendesak dan terhadap masalah-masalah keadilan sosial. Teori Nonet \& Selznick mengembangkan hukum yang responsif bertujuan untuk memberikan teori tentang pemenuhan kebutuhan-kebutuhan demikian tersebut. Nonet \& Selznick mengembangkan teori ini dengan menyajikan tiga tipe hukum dalam masyarakat. Ketiga tipe hukum tersebut adalah (1) hukum represif, yaitu hukum sebagai abdi kekuasaan represif, (2) hukum otonom, yaitu hukum sebagai intitusi yang dibedakan dan mampu untuk menjinakkan represi serta untuk melindungi integritasnya sendiri, dan (3) hukum responsif, yaitu hukum sebagai fasilitator dari responsif terhadap kebutuhan-kebutuhan sosial dan aspirasi-aspirasi sosial.

Berseiring dengan pergeseran ilmu hukum di atas pada dimensi yang lain terjadi pegeseran paradigma administrasi negara, dari Traditional Public administration menuju New Public Administration. Pada Traditional Public Adminstrations orientasi administrasi negara, lebih ditekankan kepada control, order, dan prediction,yang sangat terikat kepada political authority, tightening control, to be given, dan following the instruction. Pada New Public Management, administrasi negara diarahkan kepada alignment creativity and empowering.Pergeseran juga terjadi pada operasionalisasi administrasi negara oleh pemerintah daerah untuk penyelenggaraan tugas dan fungsi menjalankan pemerintahan sehari-hari. Dalam rangka pelaksanaan tugas dan fungsi administrasi negara pada sektor pendidikan, kesehatan, dan ekonomi masyarakat oleh pemerintah daerah saat ini telah mengalami satu proses pergeseran, yaitu dalam perkembangan konsep Ilmu Administrasi Negara. Dalam hal ini terjadi pergeseran pandangan dari administration of public dimana negara sebagai agen tunggal implementasi fungsi negara/pemerintahan, atauadministration for public yang menekankan fungsi negara/pemerintahan yang bertugas dalam public service, ke administration by public yang berorientasi dan berpandangan bahwapublic demand are differentiated, dalam arti fungsi negara/pemerintah hanyalah sebagai fasilitator, katalisator yang bertititik tekan pada putting the customers in the driver seat. Pada saat ini, determinasi negara/pemerintah tidak lagi merupakan faktor atau aktor utama atau sebagai driving force. Pendapat tersebut menegaskan adanya fenomena perubahan besar, dari peran tunggal negara sebagai penyelenggara pemerintahan, bergeser menjadi fasilitator saja.

Untuk meninggalkan paradigma administrasi klasik dan Reinventing Government atau New Public Management, dan beralih ke paradigma New Public Service, administrasi publik harus (a) melayani warga masyarakat bukan pelanggan (serve citizen, not customers),(b) mengutamakan kepentingan publik (seek the public interest), (c) lebih menghargai warga negara daripada kewirausahaan (value citizenship over entpreneurship), (d) berpikir strategis, dan bertindak demokratis (think strategic, act democratically), (d) menyadari bahwa akuntabilitas bukan merupakan suatu yang mudah (recognize that accountability is not simple), (e) melayani dari pada mengendalikan (serve rather than steer), dan (f) menghargai orang bukannya produktivitas semata (value people, not just productivity). Paradigma baru pelayanan publik (New Public Services Paradigm) sudah saatnya diarahkan pada "democracy, pride and citizen".

Lebih lanjut, dapat dikatakan bahwa "public servants do not deliver customer service, they deliver democracy". Oleh sebab itu, nilai-nilai demokrasi, kewarganegaraan dan pelayanan untuk kepentingan publik sebagai norma mendasar dalam penyelenggaraan administrasi publik. Pengaturan penyelenggaraan pelayanan publik didasarkan pada UndangUndang Dasar Negara Tahun 1945. Undang-Undang Dasar Negara 1945 merupakan landasan 
dasar filosofis bagi pengaturan pelayanan publik. Dalam Undang-Undang Dasar negara Republik Indonesia 1945 mengamanatkan bahwa kewajiban pemerintah sebagai penyelenggara utama pelayanan publik untuk melayani kebutuhan publik yang lebih baik sesuai dengan prinsipprinsip tata kelola pemerintahan yang baik (good governance) dan demokratis. Amanat ini tercermin dalam Pasal 18 ayat (2), ayat (6), Pasal 28 B ayat (2), Pasal $28 \mathrm{C}$ ayat (1), Pasal $28 \mathrm{D}$ ayat (2), Pasal $28 \mathrm{~F}$, Pasal $28 \mathrm{H}$ ayat (1), Pasal $28 \mathrm{i}$ ayat (2) Undang Undang Dasar Negara Republik Indonesia 1945. Pasal-pasal tersebut merupakan amanat negara bahwa penyelenggaraan pelayanan publik harus dikelola, diatur dan diselenggarakan untuk melayani kebutuhan masyarakat.

\section{Penutup}

Pelayanan publik pada sektor pendidikan, kesehatan, dan ekonomi masyarakat dewasa ini menghadapi suatu kecenderungan perkembangan penyelenggaraan pemerintahan daerah sebagai akibat adanya globalisasi dan otonomi daerah. Dalam manajemen pemerintahan daerah, sebuah perubahan dan pembaharuan sangatlah diperlukan agar pemerintah senantiasa dapat mengakomodasi kebutuhan perubahan dalam masyarakat dan memungkinkan administrasi publik menata kembali kehidupan masyarakat. Salah satu kecenderungan akan perlunya birokrasi publik melakukan reformasi bahwa birokrasi pemerintah daerah harus semakin terbuka dalam hubungannya dengan kepentingan publik. Dengan kata lain birokrasi pemerintah daerah dapat menjadi lebih fleksibel sehingga dapat lebih mudah menyesuaikan diri dengan perkembangan keadaan. Dengan adanya reformasi administrasi menuju public service, diharapkan dapat mendorong terwujudnya pemerintahan yang baik, memperbaiki kinerja dan memperbaiki praktek administrasi yang tidak sehat.

\section{Daftar Pustaka}

Caiden, G.E. (2001). Administrative Reform. In Farazmand. Handbook of Comparative and Development Administration. New York: Marcel Dekker, Inc.

Denhardt, Janet V. \& Robert B. Denhardt. (2010). "The New Public Service: An Approach to Reform". International Review of Public Administration 8 (1).

Denhardt, Janet V. \& Robert B. Denhardt. (2010). The New Public Service: Serving, not Steering. Armonk, New York: M.E Sharpe.

Dye, Thomas R. (2011). Understanding Public Policy. Englewood Cliffs, NY: Prentice-Hall International, Inc.

Goggin, Malcolm L, Ann O'M. Bowman, James. P. Lester, and Laurence J. O'Toole. (2001). Implementation Theory \& Practice: Toward a Third Generation. Illionis: Glenview.

Grindle, Merilee S. (2010). Politics and Policy Implementation in the Third World. Princeton, NJ: Princeton University.

Katz. S.M. (2007). Modernisasi Administrasi dan Pembangunan Nasional. Jakarta: Bumi Aksara.

Osborne, David \& Ted Gaebler. (2003). Reinventing Government (Mewirausahakan Birokrasi): Sepuluh Prinsip untuk Mewujudkan Pemerintahan Wirausaha. Jakarta: PPM.

Riggs. F.W. (2006). Administrasi Pembangunan. Jakarta: Rajawali.

Wahab, Abdul. (2017). Analisis Kebijakan dari Formulasi ke Implementasi Kebijakan Negara, Edisi Kedua. Jakarta: Bumi Aksara.

Winarno, Budi. (2008). Kebijakan Publik: Teori dan Proses, Edisi Revisi. Yogyakarta: Media Pressindo. 